\title{
Lokalitas Tafsir Nusantara: Dinamika Studi al-Qur'an di Indonesia
}

\author{
Ahmad Zaiyadi \\ Email: ahmadzaiyadigamail.com \\ (Dosen Sekolah Tinggi Ilmu al-Qur'an Walisongo)
}

\begin{abstract}
Abstrak
Tafsir Nusantara is a manifestation of the assessment and Quranic writing in Nusantara. The arrival of a Al-Qur'an interpretation in Nusantara can not be separated from the process of the assessment and writing it as part of an effort by Ulama' in understanding and spread the Islamic Teachings. In this context, Locality of the nuance also coloring variety of Quranic interpretation, both in assesment of the Quranic interpretation in mushalla, mosque, and Islamic boarding school and the writing of interpretation by using local symbolic in form like pegon or latin. In other aspect, the contribution of Middle East Ulama influences many Nusantara ulama's thats makes genealogy of thought that forming a different tendency in each season. This is seem to the figure of Jalaludin As-Suyuti with Tafsir Al-Jalalain in the form of Ijmaly interpretation, very influences on tafsir nusantara's products in the classic time such as Tarjuman Al-Mustafid writing by Abdur Rauf AsSinkili. In the modern times, the figure of Muhammad Abduh through his masterpiece Tafsir Al-Manar, by using tahlily method and Adab alIjtima' $i$ approach also give very strong influence to the birth of local Ulama's products. Starting from Tafsir Al-Qur'an Al-Karim by Muhammad Yunus, Tafsir Al-Azhar by Buya HAMKA and Tafsir AlMisbah by Quraish Shihab also using social approach. Its culmination, when the influence of modern linguistic in the contemporary period with contextual approach like Major Times of Qur'an by Fazlur rahman inspires scholars nusantara's thought as the figure of Nurcholis Majid who influences of research thematic verses interpretation in islamic universities. Thus, this study will focus on local Ulama interpretation in the dynamics of the Al-Quran study in indonesia that growing now, as was the theme of social includes, terminology of Kafir, Ahlul Kitab and Non-Muslims.
\end{abstract}

\section{Pendahuluan}

Dinamika tafsir al-Qur'an merupakan proses dialektiks antara teks al-Qur'an, pemikiran manusia serta realitas sosial pada aspek lain. Secara normatif, tekstualitas al-Qur'an memiliki kebenaran mutlak dan mengikat bagi umat Islam. Hal ini, tentu selaras dengan fungsi al-Qur'an sebagai hudān li an-nās (petunjuk bagi manusia) dan 
mashādir al-ahkām (sumber hukum), mendorong umat Islam untuk selalu merujukkan problem-problem kehidupan kepada keteranangan ayat-ayat al-Qur'an. Dengan begitu, otentisitas al-Qur'an sebagai firman Allah tak terbantahkan kebenarannya, umat Islam hanya perlu melakukan proses penafsiran dan pengembangan atas ayat-ayat al-Qur'an baik tentang masalah hukum syari'at maupun petunjuk pengetahuan tentang kehidupan. ${ }^{1}$

Teks al-Qur'an yang terbatas, berbanding terbalik dengan pemikiran manusia yang terus berkembanga seiring dengan berkembangnya zaman. Hal ini, tampak pada beragamnya produk tafsir al-Qur'an dari masa klasik hingga kontemporer. Pada masa klasik, produk penafsiran banyak mengandalkan kekuatan riwayat dari rasul dan para sahabanya yang sangat berpeangruh pada pemikiran mereka, seperti Jami' al-Bayān àn Ta'wil al-Qur'an karya Muhammad ibn Jarir Al-Ṭabāry (224-310 H.), Tafsir al-Qur'an al-Adhīm karya Imamuddin Abu Fida' al-Quraysyi (7000-774 H.) dan al-Dūrr al-Mașūr fi al-Tafsir bi al-Ma'thur karya Jalāluddin al-Syuyuti (849-911 H.), sedangkan produk tafsir kontemporer banya dilakukan tokoh-tokoh intelektual muslim yang memiliki semangat pembaharuan Islam, seperti The Mayor Themes of Qur'an karya Fazlur Rahman, Qur'an: Pluralism and Liberation karya Farid Essack dan al-Kitāb wa alQur'an: Qirā'ah Muásyirah karya Muhammad Shahrur.

Keragaman produk tafsir sebagaimana disebutkan daitas, memiliki semangat dan kecenderungan berbeda. Menurut Abdul Mustaqim, perkembangan tafsir jika ditinjau dari kedua aspek tersebut atau meminjam istilah Ignaz Goldziher sebagai the spirit of idea, maka dapat dipetakan terhadap masa formalisme idoelogis, afirmatif mitis, rasional teologis dan modern. ${ }^{2}$ Pada masa formalisme produk penafsiran belum terbntuk dalam naskah kitab tafsir sebab rasul dan sahabat seakan menjadi kamus berjalan dalam menafsirkan al-Qur'an. Hingga pada masa tabi'tabi'in pengaruh rasul dan sahabat tetap kuat, sehingga produk penafsirannya pun tidak lepas dari data-data riwayat keduanya yang bersifat afirmatif. Kondisi demikian menjadi cikal-bakal lahirnya metode Tafsir bi al-Ma'thur yang menaruh perhatian lebih terhadap aspek riwayat.

\footnotetext{
${ }^{1}$ Komaruddin Hidayat, Bahasa Agama, (Jakarta: Mizan Group, 2007), 54.

${ }^{2}$ Abdul Mustaqim, Epistemologi Tafsir Kontemporer, (Yogyakarta: LkiS, 2009), 30.
} 
Terlepas dari dominasi produk tafsir bi al-Ma'thur pada masa afirmatif, munculnya embrio ijtihad dalam tafsir tak terelakkan, hingga menjelma sebagai distingsi sumber riwayat yang menandai suatu kecenderungan baru penafsiran, yakni Tafsir bi al-Ra'y. Meskipun kepercayaan terhadap kekuatan aql (rasio) dalam kecenderungan ini pada dasarnya merupakan afirmasi dari keterangan riwayat, namun pada masa perpecahan berbagai aliran madhab, kecenderungan al-Ra'y semakin subur yang digunakan para pemeluknya untuk menguatkan madhab masing-masing. Pengaruh madhab aliran toelogi begitu kuat, menempatkan penafsiran sebagai bentuk rasionalisasi terhadap pokok-pokok permasalah teologi. Dengan demikian pada masa ini aspek teologi rasional menjadi semangat penafsiran.

Dalam teologi rasional pertarungan aliran madhab, ideologi Mu'tazilah mengambil sikap kontra terhadap konsep-konsepsi keagamaan sebagaimana yang dianut dalam metode bi al-Ma'thur. ${ }^{3}$ Setelah pengaruh aliran Mu'tazilah berkuasa pada masa Abbasiyah memunculkan banyak muncul berbagai produk tafsir bi al-Ra'y dalm berbagai corak seperti Tafsir al-Kassyaf an Haqāit al-Tanzīl karya Zamakhsary corak Ijtihadi, Ahkām Al-Qur'an karya Al-Jașṣaṣ Ayāt al-Ahkam karya Ali As-Sayis corak fiqhy, Jawāhir fi Tafsir al-Qur'an al-Karīm karya Tantawy Jawhari dan Tafsir al-Kabìr karya Muhammad Fakhruddin al-Razi yang memiliki corak falsafi, bahkan memenculkan kecenderungan baru dalam dunia tasawuf dengan produk tafsir bercorak sufi seperti Ruh al-Ma'ani karya Alusy.

Kecenderungan dengan corak keilmuan yang berbeda dalam penafsiran merupakan ambang mamasuki masa modern. Muhammad Abduh dengan karya monumentalnya Tafsir al-Manār memberi cela terhadap kajian tafsir yang bersifat multidisipliner pengetahuan. Dengan tafsirnya ia berusah untuk memberi kehidupan dalam setiap teks al-Qur'an yang dapat dipahami oleh seluruh umat manusia, penjelasan tafsirnya yang menggunakan bahasa sosial kemasyarkatan mampu menciptakan nuansa baru dalam tafsir. Ragam keilmuan modern dapat digunakan sebagai pendekat tafsir untuk memahami makna yang tersirat dalam teks.

Hadirnya Abduh, tentu menginspirasi intelektual muslim lain, seperti ulama' tafsir di Nusantara yang sedikit banyak telah dipengaruhi sosok abduh. Meskipun, pertumbuhan penafsiran terhadap al-Qur'an di Nusantara telah dilakukan sejak abad

\footnotetext{
${ }^{3}$ Ignaz Goldziher, Madhāhib al-Tafsir al-Islamy,(Beirut: Dār al-Iqra', ttp). 129.
} 
ke- 16/17. ${ }^{4}$ Hal tersebut terbukti dengan ditemukannya naskah tafsir Surah al-Kahfi (18):9 yang tidak diketahui secara pasti penulisnya. Namun dapat diperkirakan naskah ini ditulis pada masa awal pemerintahan Sultan Iskandar Muda (1607-1636). Satu abad kemudian muncullah karya tafsir yang ditulis oleh Adb al-Ra'auf al Sinkili dengan judul Tarjuman al-Mustafid. Kemudian pada abad ke-19 muncul karya tafsir yang berjudul Kitab Fara'idul Qur'an dengan menggunakan bahasa Melayu-Jawi. Sejak saat itu tafsir al-Qur'an terus bermunculan. Mulai dari Tafsir Qur'an Karim Bahasa Indonesia karya Mahmud Yunus (1922), Tafsir al- Qur'an al-Nur karya Hasbi AshShiddieqy (1952), Tafsir al-Azhar karya Hamka (1958) hingga Tafsir Al-Misbah karya Quraish Shihab (2000).

Lokalitas Tafsir Nuusantara tentu memiliki memiliki perbedaan kecenderungan penafsiran pada tiap masanya. Hal ini, tidak lepas dari setting social masayarakat nusantara, dengan ragam latar budaya berbeda. Namun, betapapun perbedaan latar belakang intelektual ulama' tafsir di Nusantara, mereka memiliki kecenderungan lokalitas yang sama. Oleh karena itu kajian terhadap produk tafsir nusantara sangat urgen, terutama berkaitan dengan Ayat-ayat tematik yang bernuansa sosial kemasyarakatan seperti, ayat tentang Kafir, Ahli Kitab dan Non-Muslim. Sebab kecenderungan lokalitas menjadi modal utama dalam permasalahan sosial yang lebih paham akan nilai budayanya sendiri.

Lokalitas Tafsir Nusantara terhadap ayat-ayat sosial-kemasyarakatan, dapat ditemukan dalam bentuk beragam, dalam wujud tafsir lengkap 30 juz seperti Tafsir AlMisbah karya Muhammad Quraish Shihab dan Tafsir Al-Azhar karya Buya Hamka atau dalam suatu tema seperti karya Muhammad Ghalib Ahl Kitab: Makna dan Cakupannya yang ditulis dalam satu buku, ada pula yang ditulis berdasarkan pembahasan bersama, seperti Tim Majlis Tarjih Muhammadiyah juga membahas tema yang sama. ${ }^{5}$ Namun, secara komprehensip, penafsiran terhadap ayat-ayat sensitif banyak disinggung para ulama' tafsir nusantara dalam tafsirnya yang tentu memiliki perbedaan dan persamaan sesuai dengan semangat kecenderungan tafsirnya.

Dengan demikian, kaijan tafsir Nusantara terhadap ayat-ayat sosial-

\footnotetext{
${ }^{4}$ Nasruddin Baidan, Sejarah Perkembangan Tafsir di Indonesia, (Solo: Tiga Serangkai, 2000), 70.

${ }^{5}$ Islah Gusmian, Khazanah Tafsir Indonesia: Dari Hermenutika Hingga Ideologi, (Yogyakarta: LkiS, 2011), 367-369.
} 
kemasyarakatan, melalui produk-produk tafsir tafsir lokal Nusantara dapat memberikan nuansa lokalitas akan sosial budaya nusantara. Islah Gusmian sebenarnya telah membahas secara panjang lebar tentang khazanah tafsri nusantara dalam konteks Indonesia, dari Hermenutika hingga Ideologi. Islah mencoba meneliti dan memetakan metode dan pendekatan tafsir di Indonesia pada abad 20 tentang tema-tema hubungan antar umat beragama, masalah gender dan juga Ahli Kitab, hanya saja, ia memfokuskan pada kitab-kitab tafsir tematik.

Dalam penelitian ini, penulis memfokuskan kajian tafsir nusantara dan kecenderungan sosial-kemasyarakatan, tentang Kafir, Jihad dan Ahli Kitab, dihadirkan melalui karya-karya tafsir Indonesia baik berupa tematik maupun penjelasan dalam tafsir utuh 30 juz. Hal ini bertujuan untuk mengoreksi kembali perbedaan penafsiran ulama' tafsir di Indonesia, dengan latar belakang intelektual, sosial dan budaya berbeda, sebagai bagian dari perbandingan penafsiran. Dalam artian, kajian terhadap sensitifitas makna teks dapat ditinjau secara obyektif dan terhindar dari Taqdis alAfkār al-Dini (penyakralan pemikiran keagamaan).

\section{Termenologi Tafsir Nusantara}

Hadirnya terminologi Islam Nusantara yang booming di Indonesia, menegaskan kembali, bahwa ajaran Islam dikenal arif terhadap budaya lokal. Dengan demikian sebelum menjelaskan terminologi Tafsir Nusantara, penulis akan menjalas lebih dulu istilah Nusantara yang banyak disinggung oleh beberapa tokoh, diantaranya adalah Azyurmadi Azra, mengganggap bahwa Nusantara adalah gambaran dari kepulauan yang mencakup kawasan-kawasan di Asia Tenggara seperti Indonesia, Malaysia, Singapura, Filliphina, Brunei Darussalam, Thailand dan Singapura. Namun pada perkembangannya istilah nusantara banyak digunakan oleh masyarakat Indonesia, bahkan melekat sebagai brand Islam di Indonesia, hal ini tampak ketika Islam Nusantara dipopulerkan oleh Nahdlatul Ulama' -Organisasi Islam terbesar di Indonesia- dan Presiden Indonesia, sebagai branding ajaran Islam yang berkembang di Indonesia saat ini.

Cakupan kepulauan Nusantara saat ini meliputi kawasan negara-negara di wilayah Asia Tenggara, menurut pendapat beberapa tokoh, kawasan Nusantara pada awalnya merupakan wilayah-wilayah yang termasuk dalam kekuasan kerajaan 
Majapahit dimasa jayanya. ${ }^{6}$ Pendapat ini banyak didukung bukti-bukti sejarah bahwa wilayah-wilayah "perdikan" taklukan Majapahit adalah kawasan yang berada dalam cakupan kepulauan Nusantara. Di satu sisi penggunaan Istilah Nusantara yang saat ini banyak digunakan masyarakat Indonesia berasal dari bahasa sangsekerta yang berarti, "Nusa" bermakna pulau atau kepulauan dan "antara" adalah kawasan diantara beberapa pulau-pulau. ${ }^{7}$

Dengan demikian, termenologi tafsir nusantara merupakan kegiatan penafsiran yang menggunakan simbol, bahasa dan dialek lokal nusantara. Meskipun, pada perkembanganya, Indonesia sebagai bagian dari kepulauan Nusantara dan mayoritas penduduknya beragama Islam, menjelma menjadi pusat kajian Islam Nusantara dan brand tafsir di Nusantara. Pemetaan Tafsir Nusantara dalam konteks di Indonesia memiliki dinamika sejarah yang cukup panjang. Penafsiran di Indonesia merupakan gamabaran dari proses penyebaran islam, sehingga kegiatan penafsiran pada awalnya merupakan kajian terhadap al-Qur'an untuk memperoleh makna-makna yang diperlukan dalam mensyiarkan ajaran-ajaran Islam. Nasruddin Baidan menggambarkan bahwa embrio tafsir di Indonesia telah ada sejak penyebaran Islam seperti halnya yang dilakukan oleh para wali dalam menjelaskan kandungan makna ayat al-Qur'an di surau dan pondok ${ }^{8}$, sehingga dalam konteks ini tafsir masih berupa penjelasan-penjelasan verbal tentang makna ayat al-Qur'an.

Berdasarkan asumsi diatas Baidan mendefinisikan tafsir di Indonesia sebagai bentuk kegiatan pemahaman terhadap kandungan makna-makna al-Qur'an melalui simbol-simbol, bahasa dan dialek lokal indonesia baik berupa bahasa verbal maupun literatur tafsir al-Qur'an. ${ }^{9}$ Penemuan literatur surat al-kahfi pada abad $16 \mathrm{M}$ menjadi bukti kitab tafsir pertama yang berbahasa melayu di Indonesia, namun demikian, kitab tersebut diperkerikan ditullis oleh Hamzah al-Fanshurȳ atau Syam al-Dīn al-Samatrani. Hanya saja selang satu abad berikutnya, penemuan produk tafsir Tarjumān al-Mustafíd

\footnotetext{
${ }^{6}$ Aksin Wijaya, Menusantarakan Islam, Menelusuri Jejak Pergumulan Islam Yang Tak Kunjung Usai, (Yogyakarta: Nadi Pustaka, 2011), 34.

${ }^{7}$ Ibid. 26

${ }^{8}$ Nasruddin Baidan, Sejarah Perkembangan Tafsir di Indonesia, (Yogyakarta: Tiga Serangkai, 2002), 21

${ }^{9}$ Ibid, 6
} 
berbahasa melayu dikarang oleh 'Abd al-Ra'üf Al-Sinkili ${ }^{10} 17 \mathrm{M}$ dikatakan oleh banyak peneliti sebagai kitab tafsir paling awal di Nusantara.

Sosok 'Abd al-Ra'ūf diyakini sebagai perintis awal penulisan tafsir di Indonesia, sehingga kedudukannya dalam jaringan ulama' berpengaruh hingga Timur Tengah. kitab tafsirnya yang dikatakan sebagai sarah atau komentar atas kitab tafsir al-Khazin, tetap dikonsumsi oleh umat Islam di Nusantara, Singapura, Penang Jakarta dan Bombay bahkan kitab tafsir tersbut, diterbitkan pula di Istanbul, oleh Mathba'ah alUstmaniyah (1302/1894 H/M), kemudian di Kairo (oleh Sulayman al-Maraghỉ dan di Mekkah) ${ }^{11}$. Dengan demikian kajian tafsir nusantara memiliki jaringan yang kuat dalam dunia Islam.

Penulisan tafsir al-Qur'an dalam bahasa lokal melayu-jawi (Arab-pegon) pada abad ke $16 \mathrm{M}$ disinyalir merupakan bagian dari adaptasi Islam terhadap entitas lokal di berbagai wilayah Nusantara, seperti tampak pada penggunaan aksara jawi dan pegon, di samping juga banyak kata serapan yang berasal dari bahasa Arab dan karya-karya sastra yang terinspirasi oleh model dan corak Arab dan Persia. ${ }^{12}$ Bahasa dan aksara dalam penulisan tafsir yang beragam juga mengindikasikan bahwa proses kajian penafsiran al-Qur'an berkembang secara dinamis, di satu sisi bahasa Arab sebagai media komunikasi al-Qur'an dipandang terlalu sukar dipahami oleh masyarakat lokal nusantara.

Namun, pada perkembangan berikutnya semangat penulisan tafsir menemui kevakuman pada abad 18-19 M. Hal ini disebabkan oleh kolonilalisme bangsa asing pada wilayah-wilayah nusantara, sehingga penafsiran al-Qur'an hanya berupa kajian terhadap produk-produk kitab tafsir yang telah ada. Menjelang berakhirnya kevakuman penulisan kitab tafsir yang berjalan cukup lama, geliat penulisan kitab tafsir mulai terlihat lagi pada abad 20-an. pengaruh Syaikh al-Azhar Kairo Muhammad Abduh

\footnotetext{
${ }^{10}$ Abd al-Ra'uf Ibn Ali al-Jawi al-Fansuri al-Sinkili (1024-1105/1615-1693 H/M.), adalah seorang melayu dari Fansur, Sinkil (singkel). Ia merupakan merupakan keturunan singkel yang menurut peneliti berasal dari Persia, ia adalah anak dari kakak laki-lakinya Hamzah Fansuri, gurunya yang paling banyak membentuk pemikirannya adalah al-Qushashy dan Syaikh Ibrahim al-Kurani selama ia belajar di Arabia. Muridnya yang terkenal adalah Syeikh Abdul Malik bin Abdullah dari Terenggano lihat, Azyurmadi Azra, Jaringan Ulama Timur Tengah dan Kepulauan Nusantara Abad, XVII-XVIII; Edisi Perenial, (Jakarta: Kencana Prenada Media Group), 2013, 239-243.

${ }^{11}$ Azyurmadi Azra, Jaringan Ulama Timur Tengah dan Kepulauan Nusantara Abad, XVII-XVIII; Edisi Perenial, Jakarta: Kencana Prenada Media Group, 2013, 257

${ }^{12}$ Anthony Jhons, "The Qur'anic in the Malay World: Reflection on Abd Ra'uf of Sinkel (1615-1693)", Journal of Islamic Studies 9:2 (1998), 121.
} 
dengan karya monumentalnya tafsir al-Manār berhasil memberikan efek stimulus terhadap geliat tafsir di wilayah Nusantara, di sisi lain kebijakan politik etis Belanda atas wilayah "jajahannya" Hindi-Belanda, nampaknya telah mengurangi beban masyarakt nusantara dalam menelorkan kreatifitasnya dalam penulisan kitab tafsir. Pada awal abad 20 mulai bermunculan geliat penulisan tafsir di nusantara, dalam hal ini Mahmud Yunus memulai penulisan tafsirnya dalam tulisan aksara jawi (bahasa Indonesia atau melayu yang ditulis dengan tulisan Arab) ${ }^{13}$ dan Ahmad Hassan pada tahun 1928, juga telah memulai menafsirkan al-Qur'an. ${ }^{14}$

Geliat penulisan kitab tafsir pada abad 20 terbilang mengalami perubahan signifikan, baik dari segi kuantitas literatur yang cukup banyak, metode dan corak dalam penafsirannya pun beragam. Sehingga banyak dari para peneliti literatur kitab tafsir al-Qur'an di Nusantara melakukan pemetaan berdasarkan pada literatur abad ini. Diantaranya adalah pemetaan tafsir yang dilakukan oleh Howard Federspiel, ia melakukan penelitian kitab tafsir berdasarkan pada aspek sosial politik yang dihadapi oleh masyarakat di Indonesia. Kemudian ia membagi ragam kajain tafsir di Indonesia pada tiga generasi, pertama pada awal abad 20 hingga awal 1960-an yang didominasi oleh penafsiran secara terpisah-pisah dan cenderung pada surat-surat tertentu. Generasi kedua yakni pada 1960-an yang dianggap sebagai penyempurna generasi pertama, dengan munculnya beberapa kitab tafsir dengan ciri terdapat catatan kaki, terjemahan kata perkata dan kadangkala disertai indeks yang sederhana. Sedangakn generasi ketiga muncul pada tahun 1970-an dengan penafsiran yang lengkap disertai dengan komentar-komentar yang luas terhadap teks dan disertai pula dengan terjemahannya. ${ }^{15}$

\section{Lokalitas Tafsir Nusantara}

Pertumbuhan dan perkembangan tafsir al-Qur'an di Nusantara tidak lepas dari proses pengakajian atas produk-produk tafsir dan proses penulisan kitab tafsir dalam ragam aksara dan bahasa yang berbeda. Secara paradigmatik kajian tafsir dapat terwujud dalam dua aspek, kajian tafsir sebagai produk yang berupa kitab-kitab tafsir

\footnotetext{
${ }^{13}$ Mahmud Yunus, Tafsir al-Qur'an al-Karim, (Jakarta: PT. Hidakarya Agung, 1973), iii

${ }^{14}$ Howard Federspiel, Kajian al-Qur'an di Indonesia, terj. Tajul Arifin (Bandung: Mizan, 1996), 39.

${ }^{15}$ Howard Federspeil, Kajian al-Qur'an di Indonesia, (Bandung: Mizan, 1995), 129.
} 
dalam berbagai bentuk dan tafsir sebagai suatu proses kegiatan "menafsirkan" melalui beberapa pendekatan dan metode penafsiran al-Qur' an ${ }^{16}$.

Kajian terhadap produk-produk tafsir al-Qur'an di Nusantara dilakukan untuk memahami makna al-Qur'an melalui beberapa kitab tafsir, mengingat bahwa tidak semua umat Islam mampu menafsirkan al-Qur'an dan sebagai awal pengenalan ajaranajaran Islam. Sedangkan, kajian atas proses penafsiran, lebih terhadap telaah kritis atas pendekatan dan metode yang digunakan mufassir (penafsir) dalam menafsirkan alQur'an. Dalam konteks ini, kedua aspek tersebut menjadi sebuah bangunan epistemologis untuk memetakan tumbuh dan berkembangnya penafsiran al-Qur'an di Nusantara.

Para peneliti kajian tafsir di Indonesia berbeda dalam memaparkan periodesasi penulisan tafsir di Indonesia. Salah Satunya adalah Howard M. Federspiel dalam bukunya yang berjudul Kajian al-Quran di Indonesia: dari M. Yunus hingga Quraish Shihab yang melakukan pembagian kemunculan dan perkembangan tafsir al-Quran di Indonesia yang berbasiskan generasi. Ia membagi periodesasi tersebut berdasarkan pada tahun, dalam tiga generasi. Generasi ke-1, kira-kira dari permulaan abad ke-20 sampai awal tahun 1960-an, yang ditandai dengan adanya penerjemahan secara terpisah dan cenderung pada surat-surat tertentu sebagai objek tafsir. Generasi ke-2, merupakan penyempurnaan atas generasi pertama yang muncul pada pertengahan 1960-an sampai tahun 1970-an, yang mempunysi ciri diantaranya terdapat beberapa catatan, catatan kaki, terjemahan kata perkata, dan kadang-kadang disertai dengan indeks yang sederhana. Sedangkan generasi ke-3 dimulai antara pertengahan tahun 1970-an, merupakan penafsiran lengkap dengan uraian yang sangat luas. ${ }^{17}$

Pemetaan tafsir yang dilakukan Federspiel banyak ditanggapi oleh peneliti berikutnya, salah satunya Islah Gusmian yang memandang bahwa periodisasi tafsir di Indonesia oleh Federspiel ini memang bermanfaat dalam rangka melihat dinamika penulisan tafsir di Indonesia. Namun, dari segi tahun pemilahannya dinilai agak rancu. Misalnya, ketika Federspiel memasukkan tiga karya tafsir, yaitu: (1) Tafsir al-Furqān karya A. Hassan (1962); (2) Tafsir al-Qur'an karya H. Zainuddin Hamidy dan

\footnotetext{
${ }^{16}$ Abdul Mustaqim, Epistemologi Tafsir Kontemporer, (Yogyakarta: Penerbit LKiS, 2009), 26.

${ }^{17}$ Howard M. Federspiel, Kajian al-Quran di Indonesia: dari M. Yunus hingga Quraish Shihab, terj. Tajul (Bandung: Mizan, 1994), 129.
} 
Fachruddin Hs.(1959), dan (3) Tafsir al-Qur'an al-Karim karya H. Mahmud Yunus, sebagai karya tafsir yang representatif untuk mewakili generasi ke-2. Padahal menurut Gusmian, ketiga tafsir itu muncul pada pertengahan dan akhir 1950-an, yang dalam kategorisasi yang ia susun masuk dalam generasi pertama. ${ }^{18}$ Setelah mengkritisi periodisasi Federspiel, Gusmian memaparkan kategori tafsir al-Quran di Indonesia dengan mengacu pada periodisasi tahun, yaitu: (1) Periode ke-1, yakni antara awal abad ke-20 hingga tahun 1960; (2) Periode ke-2, tahun 1970-an sampai tahun 1980-an. (3) Periode ke-3, antara 1990-an hingga seterusnya. ${ }^{19}$

Pada bagian lainnya, Nashruddin Baidan dalam bukunya yang berjudul Perkembangan tafsir al-Quran di Indonesia memaparkan periodisasi yang agak berbeda dengan Federspiel maupun Gusmian. Baidan membagi periodisasi perkembangan tafsir di Indonesia dalam empat periode, yaitu: (1) periode klasik, dimulai antara abad ke-8 hingga abad ke-15 M. (2) periode tengah, yang dimulai antara abad ke-16 sampai abad ke-18, (3) periode pramodern yang terjadi pada abad ke-19, (4) adalah periode Modern, yang dimulai abad ke-20 hingga seterusnya. Periode modern ini dibagi lagi oleh Baidan menjadi tiga bagian yaitu: kurun waktu pertama (1900-1950), kurun waktu ke-2 (19511980), dan terakhir adalah kurun waktu ke-3 (1981-2000). ${ }^{20}$

Perbedaan periodisasi diatas, bisa terjadi antara lain disebabkan karena terdapat perbedaan data yang diperoleh oleh para peneliti perkembangan tafsir di Indonesia. Selain itu perbedaan sudut pandang tentang objek kajian, bisa menjadi salah satu sebab timbulnya perbedaan pemilahan tahun yang terjadi di antara tafsir-tafsir di atas. Dalam kajian ini, penulis disini bukan berada dalam posisi sebagai pengkritik terhadap periodisasi yang telah dipaparkan diatas. Dengan demikian berdasarkan pemetaan dari beberapa peneliti diatas, dapat disimpulkan beberapa periodesasi untuk saling melengkapi satu dan lainnya.

1. Periode Klasik

Karya-karya tafsir pada periode ini dapat ditelaah sebelum bad ke- $20 \mathrm{M}$, dengan beberapa kecenderungan, pertama, penafsiran yang dilakukan bergerak dalam model yang sederhana serta tekhnis penulisan yang tergolong elementer. Dalam naskah

\footnotetext{
18 Islah Gusmian, Khazanah Tafsir Indonesia; dari Heurmeneutika hingga Ideologi (Jakarta: Teraju, 2003), 65

${ }^{19}$ Ibid., 66-69.

${ }^{20}$ Nashruddin Baidan, Perkembangan Tafsir di Indonesia (Solo: Tiga Serangkai, 2003), 31-109.
} 
tafsir surat al-Kahfī yang disimpan dimuseum Cambridge misalnya, tidak ada pemisahan ruang antara teks arab al-Quran, terjemah dan tafsirnya. Ketiganya diletakkan dalam halaman yang sama tanpa pemisahan yang tegas kecuali warna tinta. Manuskrip ini menulis surat al-Kahfĩ dalam tinta merah diiringi dengan terjemah serta komentar dalam tinta hitam. Model seperti ini menurut Feener memang terus diterapkan didunia melayu sampai abad ke-19. ${ }^{21}$

Kecenderungan yang kedua dan ketiga pada dasarnya merupakan titik persinggungan antara tafsir dan budaya lokal. Hal ini dapat ditelaah dari aspek tulisan yang dipakai rata-rata adalah huruf pegon ${ }^{22}$ baik dalam bahasa Melayu, Jawa maupun Sunda. Hal ini dimungkinkan terjadi karena pada akhir abad ke-16 terjadi adaptasi Islam terhadap entitas lokal di berbagai wilayah Nusantara. Misalnya huruf ini dipakai dalam tafsir Tarjumān al-Mustafid serta naskah Surat al-Kahfí dan naskah anonim lainnya yakni Kitab Fara'id al-Qur'an ataupun Jam'u al-jawāmi ‘ al-musannafăt. ${ }^{23}$ Persinggungan penafsiran al-Quran dengan budaya lokal juga terjadi dalam aspek sufisme yang kala itu kental mewarnai keberislaman penduduk Nusantara utamanya kawasan Melayu (Sumatra) dan Jawa. Walaupun A. John merasa heran dengan sedikitnya tafsir sufistik yang ditemukan, karena memang awal kegiatan intelektual di kawasan ini masih didomonasi oleh tradisi lisan (oral tradition) dalam melakukan transmisi ilmunya kepada orang lain, sehingga menelusuri diskursus bidang tafsir sulit dilakukan melalui bukti-bukti karya tulis. Faktor lain yang menghambat penemuan karya tafsir sufistik adalah adanya benturan tasawuf heterodoks Hamzah al-Fansuri dan Syams al-Dīn al-Sumatrani dengan tasawuf ortodoks Nurudin al-Rānirīi yang berujung dengan pembakaran karya-karya tulis. Tetapi, hasil karya persentuhan tasawuf dengan penafsiran al-Qur'an dapat dilihat dari fregmen sufistik Tasdiq alMa 'ārif yang tak bertahun. ${ }^{24}$

\section{Periode Modern}

\footnotetext{
${ }^{21}$ Michael R. Feener, "Notes Towards", dalam Studia Islamika, Vol. 5, No. 3, 1998, 47.

22 Aksara pegon adalah teks-teks Jawa, Sunda ataupun Melayu yang ditulis dalam aksara Arab. Di komunitas muslim yang tersebar dalam masa periode klasik ini, aksara pegon menjadi aksara yang lebih populer dibanding variasinya, yakni hurup gundil (hurup gundul). Karena kondisi keilmuan masyarakat muslim pada waktu itu belum begitu tinggi dalam bahasa arab. Untuk melihat secara lengkap sejarah aksara pegon dalam Jawa dan Sunda

${ }^{23}$ Gusmian, Khazanah Tafsir, 61

24 A. H. Jons, "Islam di Dunia Melayu" dalam Azyumardill Azra (ed.) Perspektif Islam Asia Tenggara (Jakarta: Yayasan Obor Indonesia, 1989), 126.
} 
Penulisan tafsir di Indonesia menemui titik kulminatif dari segi teknis penulisan yang lebih baik dan mencapai produktivitas yang mulai tinggi pada awal abad 20 Hingga Tahun 1970-an. Hal ini disebabkan beberapa faktor. Pertama adalah kebijakan politik makro yang dilakukan oleh Kolonial Belanda yakni politik etis di akhir abad ke-19 sampai awal abad ke-20 mulai terasa dampaknya. Kebijakan yang salah satu poinnya adalah memajukan edukasi bangsa Indonesia ini, mulai memunculkan kesadaran intelektual dari sebagian masyarakat Indonesia. Kaum terdidik yang naik ke permukaan baik dari bidang politik ataupun agama mulai menempati pos-posnya sebagai motor penggerak pemikiran. Termasuk dalam hal ini banyak mufassir-mufassir yang lahir dan mulai menuliskan karyanya. Kedua adalah peranan penting dari dunia percetakan di Indonesia yang memudahkan untuk menulis karya termasuk karya tafsir untuk kemudian disampaikan kepada masyarakat Indonesia. ketiga dan juga faktor yang paling penting adalah pengaruh dari pemikiran Muhammad Abduh yang mempunyai semboyan "kembali kepada al-Quran" membuat kebutuhan untuk menafsirkan al-Qur'an semakin mendesak.

Arus modernisasi yang sudah mulai menyentuh kehidupan beragama masyarakat Islam di Nusantara berpengaruh terhadap kemajuan penulisan dalam bidang tafsir. Ciri perkembangannya pun berjalan seiring dengan perubahan intelektual masyarakat ketika itu. Dari segi tata letak, bila dibandingkan teknik lay-out penulisan tafsir pada periode klasik yang belum memisahkan ruang teks al-Quran, terjemah dan tafsirnya, dimana ketiganya masih diletakkan dalam halaman yang sama tanpa pemisahan yang tegas kecuali warna tinta, maka seiring dengan mode, cetakan di awal abad ke-20 mulai dikembangkan teknik lain yang lebih sistematis. Perbedaan teknik lay-out terletak pada Penulisan teks Arab al-Quran yang agak renggang secara berurutan untuk membagi ruang bagi penulisan terjemahan atau tafsir disela-sela garisnya. Dengan kata lain, teknik yang dikembangkan ini adalah membagi setiap halaman menjadi 2 ruang, yaitu satu untuk teks Arab dan satunya untuk terjemahan. ${ }^{25}$ Bahkan untuk tahun-tahun selanjutnya dikembangkan penempatan tafsir atas teks terjemah terpisah dalam bentuk catatan kaki atau catatan pinggir. Tafsir yang menggunakan teknik ini salah satu contohnya adalah tafsir Raudlah al-'Irfän karya Ahmad Sanūsì.

\footnotetext{
${ }^{25}$ Feener, "Notes Toward", 55-56.
} 
Pada sisi lain, proses penterjemahan terhadap al-Qur'an mengindikasikan bahwa modernisasi dalam kajian islam dapat dipandang sebagai suatu kebutuahan bagi umat Islam. Sebagai contoh penafsir yang berani melakukan terobosan ini dapat dikemukakan misalnya Mahmud Yunus. Disebut berani karena ia menerjemahkan alQuran ke dalam bahasa selain bahasa Arab secara utuh ditengah-tengah masyarakat yang menganggapnya haram. Saat itu menerjemahkan dan menafsirkan al-Qur'an di luar bahasa Arab belum dapat diterima oleh semua ulama. Karyanya adalah tafsir alQur'ān al-Karim (1922) dalam bahasa Indonesia. ${ }^{26}$ Tokoh lain yang melakukan hal serupa adalah Ahmad Sanūsì yang menerjemahkan al-Qur'an dalam bahasa Indonesia dalam karyanya Tamsyiyyah al-Muslimin dan dengan karyanya Malja' al-Talibïn serta Raudlah al- 'Irfän dalam bahasa Sunda.

Dengan demikian karakteristik perkembangan tafsir pada periode modern terletak pada penggunaan bahasa dengan huruf Latin yang menggeser kepopuleran hurup pegon, selain diintrodusirnya aksara Roman oleh Pemerintah Belanda. Proses "Romanisasi" atau "Latinisasi" ini, pada akhirnya menjadi dominan dari pusat hingga daerah, terutama setelah dihapuskannya sistem tanam paksa yang kemudian diikuti penerapan kebijakan politik etis. Disamping itu munculnya media massa, terutama koran dan majalah pribumi, pada dekade 1900-an seperti media massa "Medan Prijaji" yang terbit pertama kali 1906 dan al-Islam pada tahun yang terbit 1916 juga mendorong romanisasi lebih jauh. ${ }^{27}$ Hal ini juga selanjutnya diikuti oleh karya-karya tafsir. Diantaranya adalah tafsir al-Furqan (1928) karya A. Hassan dan tafsir Tamsyiyyah al-Muslimin (1934) karya Ahmad Sanusi.

Namun, aksara pegon sebagai pengungkap dalam karya tafsir tidak hilang sepenuhnya dan masih bisa didapati sampai setidak-tidaknya dekade 1980-an. Kita bisa menyebut beberapa karya misalnya: tafsir al-Qur'an al-Kariim (1922) karya Mahmud Yunus; tafsir al-Burhan (1922), tafsir Juz 'Amma karya Hamka; tafsir Malja' al-Thalibiin (1931) karya Ahmad Sanusi; dan tafsir al-Ibriz (1980) karya KH. Bisri Musthofa. Dalam karya-karya periode modern, juga bisa dilihat kecenderungan penafsiran pada surah-surah tertentu. Misalkan, Tafsir al-Qur'an al-Karim, Yaasin

\footnotetext{
${ }^{26}$ Mamat S. Burhanuddin, Hermeuneutik al-Qur'an ala Pesantren: Analisis Terhadap Tafsir Marah Labid Karya K.H. Nawawi Banten (Yogyakarta: UII Press, 2006), 116-117.

${ }^{27}$ Gusmian, Khazanah Tafsir, 61-62.
} 
(Medan: Islamiyah, 1951) karya Adnan Yahya Lubis; Tafsir Surah Yasin Dengan keterangan (bangil : Persis 1951) Karya A. Hasan kedua Literatur Tafsir ini berkonsentrasi pada Surah Yasin. Dari segi aspek teknis lainnya kita juga bisa melihat sudah dimulainya sistem penulisan yang menyertakan cara baca dalam huruf latin beserta terjemah dan tafsirnya, seperti Tafsir Tamsyiyyah al-Muslimin (1934) karya Ahmad Sanusi, Tafsir Rahmat (1981), dan Terjemah dan Tafsir al-Qur'an: Huruf Arab dan Latin (1978) karya Bachtiar Surin.

\section{Periode Kontemporer}

Dinamika kajian dan penulisan tafsir di Indonesia pada periode kotemporer bergerak mulai dari tahun 1980-an sampai sekarang. Istilah kontemporer banyak didengungkan dalam aspek kajian linguistik modern untuk membaca simbol-simbol bahasa kebudayaan hingga realitas sosial. Namun, lambat laun paradigma ini menjadi suatu kecenderungan penafsiran melalui multidisipliner yang tidak lagi terikat oleh batasan-batasan kaidah literer teks al-Qur'an. Proses penulisan tafsir di era kontemporer juga menekankan pada penyelesaian sebuah topik tertentu yang dikenal dengan metode Tafsir Maudlu'i. Meskipun bentuk penafsiran tematik ini telah lama dipakai oleh para penulis Islam klasik, tetapi pada tahun-tahun belakangan ini dikembangkan secara sempurna oleh Fazlurrahman, seorang tokoh intelektual dunia Islam kontemporer dalam bukunya Mayor Themes of The Qur'an.

Kecenderungan penafsiran para pemikir kontemporer juga banyak diintrodusir di Indonesia seperti Nurcholish Madjid dan Syafi'i Ma'arif sangat banyak mempengaruhi perkembangan intelektual di Indonesia, khususnya IAIN. Sebagai contoh dalam priode ini misalnya Tafsir Ayat-ayat Haji: Telaah Intensif dari Pelbagai Madzhab, karya Mukhtar Adam. Dalam karyanya ini dibahas satu topik tentang ibadah haji dengan memakai perpaduan antara metode penafsiran Maudu'i dengan metode perbandingan madzhab. ${ }^{28}$ Tafsir sejenis yang memakai metode yang hampir serupa adalah Tafsir dan Uraian Perintah-perintah dalam al-Qur'an, yang ditulis oleh Q.A . Dahlan Saleh.

Disamping itu dalam priode kontemporer ini, topik-topik yang dibahas juga semakin meluas. Para penulis tafsir tidak hanya terbatas dari kalangan ahli agama

\footnotetext{
${ }^{28}$ Mamat S. Burhanuddin, Hermeuneutik al-Qur'an ala Pesantren: Analisis Terhadap Tafsir Marah Labid Karya K.H. Nawawi Banten (Yogyakarta: UII Press, 2006) 128.
} 
semata namun dari kalangan ahli komunikasi pun seperti Jalaluddin Rahmat dapat menulis sebuah karya tafsir yang berjudul Tafsir bi al-Ma'tsur: Pesan moral al-Qur'an. Awalnya buku ini berasal dari serial artikel republika. Di dalam buku ini Jalaluddin Rahmat mengadopsi metode Tafsir bi al-ma'tsur atau menafsirkan ayat al-Qur'an dengan ayat al-Qur'an yang relevan. Namun ia tidak menafsirkan seperti para penafsir konvensional metode riwayat yang lain yang menjelaskan ayat demi ayat dengan tertib ayat.

Masih dalam dekade yang sama muncul karya Dawam Raharjo berjudul Ensiklopedi al-Qur'an. Buku ini ditulis setebal 700 halaman yang semula dimuat secara berkala dalam jurnal 'Ulum al-Qur'an. Di sini Dawam membahas tema-tema besar yang aktual seperti 'adil', 'agama', 'ilmu pengetahuan' dan sebagainya. Karya terakhir dalam generasi ini yang sangat populer adalah karya Quraish Shihab. Ia sangat dikenal melalui koleksi tulisannya yang dibukukan dengan judul Membumikan al-Qur'an. Buku ini telah banyak memperkenalkan konsep metode Maudlu'i dengan bahasa Indonesia yang lugas. Di samping itu, penerapan praktis terhadap metode tematik ini terlihat dalam beberapa karyanya yang lain seperti: Wawasan al-Qur'an, Tafsir alQur'an al-Karim dan lain-lain. Karya-karya Quraish Shihab ini banyak diakui oleh pemerhati perkembangan tafsir Indonesia sebagai inovator baik dalam segi metode penafsirannya maupun isinya. $^{29}$

Dengan demikian, dapat dikatakan bahwa mulai abad ke-20 dinamika penafsiran di Indonesia memiliki kecenderungan metode penafsiran yang menggunakan pendekatan linguistik modern dan tradisi penulisan tematik. Kecenderungan ini bertahan hingga saat ini dalam berbagai bentuk mulai penelitian akademik dalam perguruan tinggi maupun non-akademik berupa penelitian lepas oleh pegiat kazanah tafsir di Indonesia. Disamping itu, kecenderungan penggunaan bahasa penafsiran yang bervariasi, mulai "sosial-kemasyarakatan", "reportase" maupun bahasa ilmiah populer juga mewarnai perkembangan tafsir.

\section{Dinamika Penafsiran Ayat-ayat Sosial-Kemasyaratan}

Kecenderungan baru penafsiran pada periode kontemporer tentu berimplikasi terhadap produk-produk penafsiran yang bersifat selektif terhadap topik-topik 
permasalahan tertentu. Pendekatan kebahasaan yang digunakan tidak sampai mengenyampingkan makna historis teks di awal turunnya hingga pemaknaannya yang berkembang saat ini. Konsep perbandingan tekstualitas ayat, juga menjadi barometer penafsiran. Hal ini tampak pada produk-produk tafsir akhir-akhir ini, terutama menyangkut topik atau tema yang multi tafsir seperti ayat-ayat tentang makna Kafir, Ahli Kitab, dan Non-Muslim. Ketiga istilah tersebut tampak sama sebagai Indentitas lain dari penganut agama selain Islam.

Pemahaman dan persepsi yang berkembang di kalangan masyarakat terhadap ayat-ayat berkaitan dengan tema-tema di atas tampak sama. Namun, jika ditelaah penafsiran terhadap ayat-ayat tersebut tentu memiliki konotasi makna tersendiri secara tekstual maupun kontekstual. Makna Kafir banyak diidentikkan dengan pemeluk agama lain yang wajib diperangi, meskipun ada pula pendapat yang membagi maknanya menjadi Kafir "Dzimmȳ "baik dari kalangan Ahli Kitab maupun NonMuslim yang dapat dilindungi karena bisa diajak kerjasama dan Kafir “Harby" yang wajib diperangi. Namun, ayat-ayat yang menyebutkan istilah Kafir dalam al-Qur'an dengan lafadz kafir dan kufr tidak hanya berkaitan dengan orang non-muslim, sebaliknya memiliki pengertian yang lebih luas lagi dan bahkan berbeda konteksnya, seperti halnya keterangan Kafir dalam hal nikmat dan lainnya.

Pemaknaan istilah Kafir yang berkembang saat ini, banyak dikaitakan dengan hubungan sosial umat Islam terhadap umat Ahli Kitab dan Non-Muslim. Meskipun Ahli Kitab dalam al-Qur'an banyak disebutkan berulang dengan lafadz Ahl Al-Kitab atau Utu Al-Kitab yang biasanya disandingkan dengan penjelasan ayat tentang bani Israil baik Yahudi Maupun Nasrani dalam konteks teologis. Persepsi tentang makna Kafir lainnya, juga dikaitkan dengan Istilah Non-Muslim, meski pada dasarnya sedikit banyak diterjemahkan mencakup unsur makna Ahli Kitab dan Kafir, ia juga dianggap lebih general hingga belum menemukan konotasi makna yang membedakannya dengan Ahli Kitab dan Kafir. Namun, akhir-akhir ini penggunaan istilah Non-Muslim banyak digunakan dalam konteks hubungan sosial yang sarat akan makna teologis. Ayat-ayat al-Qur'an yang dijadikan rujukan dalam persoalan ini biasanya mengacu pada surat Ali Imron ayat 28, Al-Nisa' ayat 139, 144 dan Al-Maidah ayat 51 dengan lafadz Kafir yang disandingkan dengan lafadz Auliya’. 
Dengan demikian pemaknaan istilah Ahli Kitab, Kafir dan Non-Muslim menyisakan persoalan penjelasan konotasi pemaknaan yang belum usai, untuk menanggapi persepsi dan pemahaman masyarakat tentang ketiganya dalam hubungan sosiologis. oleh karena itu, penulis akan sedikit memaparkan beberapa penafsiran ulama' di Indonesia tentang makna Kafir, Ahli Kitab dan Non-Muslim.

1. Kafir

Persepsi masyarakat tentang istilah kafir merupakan predikasi bagi seluruh pemeluk agama selain Islam. Sekilas tampak jelas dan benar dalam ranah keyakinan teologis, namun pengertian ini akan menyisakan persoalan ketika ditarik dalam ranah sosiologis yang banyak dijadikan sumber radikalisme antar umat beragama. Pada dasarnya istilah kafir begitu akrab dipakai dengan berbagai ragam makna. Negaranegara "Barat" Amerika dan Eropa dengan populasi masyarakat Non-Muslim yang dominan, oleh sebagian kelompok muslim di Indonesia, diklaim sebagai kafir, dengan alasan di samping mereka dipimpin oleh orang non-muslim, juga visi politiknya (dianggap) selalu merugikan umat islam. ${ }^{30}$ Bahkan di tahun 1920-an, di Indonesia, pertentangan antar umat Islam sendiri, karena persoalan furu'iyyah, juga telah memunculkan tuduhan yang menggunakan term kafir. Fenomena ini bisa dilihat misalnya dari perseteruan kelompok Majlis Ahli Sunnah dan Persis Bandung dengan Al -Ittihadul Islamiyyah, yang terjadi pada tahun $1927 .^{31}$

Secara termenologis asal istilah kafir banyak didasarkan pada penjelasan ayatayat al-Qur'an yang disebutkan dalam bentuk lafadz kafara, kufr dan kafir yang memiliki makna asal menyembunyikan, seperti penafsiran Hamka atas manka kafir pada surat al-Baqarah ayat 6 yang dikorelasikan dengan keterangan dalam surat AlHadid ayat 20 tentang seorang petani yang menyembunyikan atau menimbun hasil panennya. $^{32}$ Dengan demikian pengertian lafadz kufr dalam ayat-ayat al-Qur'an memiliki makna beragam, tidak hanya berkaitan dalam masalah teologis. Ayat-ayat alQur'an tentang kufr secara semantik merupakan bangunan konseptual kufr sebagai predikat suatu tindakan.

\footnotetext{
${ }^{30}$ Islah Gusmian, Khazanah Tafsir Indonesia, (Jakarta, Teraju, 2002) hal. 299

${ }^{31}$ Mohammad Iskandar, Para Pengemban Amanat, (Yogyakarta, Bulan Bintang, 1992) hal. 168

${ }^{32}$ Hamkan, Tafsir Al-Azhar, (Jakarta: Pustaka Panji Mas, 2002), Juz, XXIV, 168.
} 
Selaras dengan Hamka, berdasarkan pelacakan Muhammad Ghalib, terma kufr ditemukan sebanyak 525 kali dalam al-Qur'an. Secara umum pengertian kufr disebutkan dalam kontesk, kafur diartikan nama suatu mata air sorga, Kuffar (bentuk jamak kafir) berarti petani, Kaffarah diberikan dalam bentuk sedekah atau berpuasa dan Kaffara, yukaffiru berarti menutupi, menghapus atau menghilangkan yang semuanya berkaitan dengan penghapusan dosa. ${ }^{33}$ Kategori predikat kufr pada termaterma diatas tentu berlaku bagi semua manusia baik muslim mapun non-muslim.

Penyempitan makna kafir dari makna-makna asalnya merupaka bias dari generalisasi ayat dalam ranah teologis, tanpa mengetahui cakupan ruang-ruang wilayahnya. menurut Cawidu, kufr memiliki tingkatan, seperti halnya syirk. Pembagian ini dia lakukan terkait dengan klaim kufr riddah yang secara institusional menyebabkan seseorang diklaim keluar dari Islam. Setelah mengutip pendapat beberapa ulama, dia membagi pengertian kufr ke dalam dua bagian utama: (1) kekafiran yang menyebabkan pelakunya tidak lagi berhak disebut Muslim. Termasuk dalam kategori ini adalah jenis kufr syirk, kufr inkar, kufr juhud, kufr nifaq, dan kufr riddah; dan (2) mencakup semua perbuatan maksiat, larangan - Nya, yang secara umum bisa disebut kufr nikmat. Pelaku dari jenis kufr yang kedua ini, menurutnya, tidaklah keluar dari islam, meskipun dia menjalani hukuman Tuhan. ${ }^{34}$

Pembagian Cawidu ini menarik, apalagi bila dikaitkan dengan implikasi hukumnya. Dalam konteks fiqh, seperti juga dikutip Cawidu, individu yang diklaim sebagai murtad, darah dan jiwanya halal, harta bendanya disita negara, mayatnya tidak dimandikan dan tidak dikuburkan di pekuburan islam. ${ }^{35}$ Secara etika sosial, kita bisa mempertanyakan hukum macam ini: mengapa kelompok kufr yang non riddah, tidak mempunyai sanksi hukum yang berat dan bersifat sosial macam itu. Padahal tindakan dalam kufr kelompok yang kedua juga mempunyai akibat buruk dalam sistem sosial kemasyarakatan yang merugikan banyak orang. Bila kita percaya, bahwa dasar dirumuskannya sebuah produk hukum adalah penghentian kejahatan, mengapa penentang moral agama itu tidak mendapat pertentangan yang tegas. Padahal, yang terakhir ini justru mempunyai implikasi sosial dalam kehidupan sosial kemasyarakatan

\footnotetext{
${ }^{33}$ Muhammad Ghalib, Ahl Al-Kitab, Makna dan Cakupannya, (Jakarta: Paramadina, 1998), 62-63

${ }^{34}$ Harifuddin Cawidu, Konsep Kufr dalam Al-Quran, hal 160-161

${ }^{35}$ Abu Bakr Jabir Al-Jaza'iri, Minhaj Al-Muslim (Beirut: Dar Al-Fikr, 1976) hal. 535
} 
secara umum. Berdasarkan pertanyaan itu, kajian atas term kufr yang dilakukan oleh Cawidu ini masih bersifat abstrak, karena ia tidak menggunakan hermeneutik sosial dalam kajiannya. ${ }^{36}$

\section{Ahli Kitab}

Makna Ahli Kitab banyak dipersepsikan sebagai pemeluk agama samawi yang identik bagi kaum Yahudi dan Nasrani. Berdasarkan keterangan ayat-ayat al-Qur'an tentang Ahli Kitab, banyak disebutkan berulang kali melalui redaksi berbeda, diantaranya, Ahl Al-Kitab sebanyak tiga puluh satu kali, Utu Al-Kitab delapan belas kali, Utu Nashiban Min Al-Kitab tiga kali, Al-Yahud delapan kali, Alladhina Hadu sepuluh kali, Bani Isra'il empat puluh satu, Al-Nashara empat belas kali dan Istilah lainnya. ${ }^{37}$ Perbedaan penggunaan redaksi pada ayat-ayat tentang Ahli Kitab tersebut, secara tekstualitas dan kontekstualitas tidak lepas dari keberadaan Kitab yang dijadikan rujukan pemeluknya, hal ini mengindikasikan bahwa tidak salah persepsi yang berkembang bahwa Ahli Kitab tidak lain merupakan para pemeluk agama samawi.

Persoalan yang berkembang saat ini justru terletak pada pengertian termenologis Ahli Kitab berserta cakupannya. Banyak pemahaman dan penafsiran yang berusaha untuk merumuskan pengertian makna ahl al-kitab dalam Al-Qur'an. Ada yang memaknainya sebagai kaum Yahudi dan Nasrani keturunan Israil, meskipun ada pula yang memaknainya lebih luas, selain kaum Yahudi - Nasrani, seperti pernyataan Nurcholis Madjid bahwa makna Ahl al-Kitab termasuk juga golongan agama lain seperti (Majusi, Shabi'in, Hindhu, Buddha, Kong $\mathrm{Hu} \mathrm{Cu}$ ) yang memiliki kedudukan sama seperti agama Yahudi dan Nasrani sebagai agama yang memiliki wahyu dengan seperangkat nilai-nilai ketauhidan terhadap Tuhan Yang Maha Esa. ${ }^{38}$

Penggunaan terma Ahli Kitab menurut Muhammad Ghalib dalam bukunya $A h l$ Al-Kitab, Makna dan Cakupannya, lebih bernuansa teologis bukan etnis. Karena itu, siapa pun, dari etnis mana pun yang menganut agama Yahudi dan Nasrani, dipahami termasuk dalam kategori ahl al-kitab. ${ }^{39}$ Keduanya memang merupakan penganut agama

\footnotetext{
${ }^{36}$ Islah Gusmian, Khazanah Tafsir Indonesia, hal. 301-302.

${ }^{37}$ Quraish Shihab, Wawasan, (Jakarta: Lentera Hati, 2000), 348.

${ }^{38}$ Nurcholish Madjid, Islam Agama Peradaban: Membangun Makna dan Relefansi Doktrin Islam dalam Sejarah. (Jakarta: Paramadina: 2000), 188-190.

${ }^{39}$ Muhammad Galib .Ahl Al-Kitab, Makna dan Cakupannya, (Jakarta, Paramadina, 1998) hal. 187
} 
sebelum Islam yang dinisbatkan pada nabi Musa dan nabi Isa dan seringkali disebutkan dalam al-Qur'an dengan istilah Bani Isra'il, yakni Yahudi sebagai penganut kitab Taurat dan Nasrani yang menganut kitab Injil. ${ }^{40}$

Hal senada juga disampaikan Quraish Shihab, dalam Wawasan Al-Qur'an cenderung memahami Ahli Kitab adalah semua penganut agama Yahudi dan Nasrani. Alasannya, karena terma itu digunakan Al-Qur'an sebatas pada dua komunitas ini. Namun ia kemudian menjelaskan terdapat perbedaan perlakuan orang Yahudi yang lebih ekslusif untuk menerima kebenaran Islam dari pada orang Nasrani ${ }^{41}$, hal ini dipertegas dengan penggunaan lafadz pada surat Al-Baqarah ayat 120 yang artinya:

“Orang-orang Yahudi dan Nasrani tidak akan senang kepada kamu hingga kamu mengikuti agama mereka"

Penggunaan lafadz lan untuk menunjukkan sikap ketidak senangan kepada ajaran Islam pada ayat diatas diperuntukkan bagi orang Yahudi yang berarti lebih tegas dalam menolak ajakan nabi Muhammad, sedangkan bagi kaum Nasrani hanya cukup dengan lafadz la tanpa adanya tanda penegasan setelahnya. ${ }^{42}$ Perbedaan perlakuan keduanya pada dasarnya dapat pula dibuktikan secara historis, kaum Yahudi yang sudah masuk Islam seperti Abdullah bin Salam sulit meninggalkan ajarannya lantaran masih mengamalkan ajaran-ajaran lama mereka seperti memuliakan sapi dan hari sabtu hingga muncul teguran dari Allah dengan diturunkannya surat Al-Baqarah ayat 208. ${ }^{43}$

Namun, penafsiran berbeda datang dari Tim Majelis Tarjih dan Pengembangan Pemikiran Islam PP. Muhammadiyah yang selaras dengan pemikiran Cak Nur, mereka berusaha menguraikan keragaman pemahaman Ulama' tentang makna ahl al-kitab secara lebih luas yang terdiri dari Yahudi, Kristen, Majusi dan Sabi'un, bahkan bisa diperluas sampai Konfusius, Hindu dan Budhha. Pada dasarnya pada era modern, perumusan makna konsep ahl al-kitab begitu terbuka dan harus selalu dilakukan oleh para sarjana Muslim untuk mengantisipasi perkembangan zaman. Upaya kearah itu harus dilakukan berdasarkan Al-Qur'an yang shalih fi kulli zaman wa makan tanpa mendeskriditkan komunitas agama tertentu yang menurut pemahaman penulis sangat

\footnotetext{
${ }^{40}$ Muhammad Husein Adh-Dhahaby, al-Tafsir wa al-Mufassirun, (Beirut: Dar Kitab al-Islamy, 1998), Jilid I, 121-122

${ }^{41}$ Quraish Shihab, Wawasan, (Jakarta: Lentera Hati, 2000), 347.

${ }^{42}$ Ibid, 348.

${ }^{43}$ Al-Wahidy, Asbab an-Nuzul al-Qur'an, (Beirut: Dar Kutub al-Islamy, 1996), 156.
} 
bertentangan dengan semangat al-Qur'an. Hal ini dimaksudkan untuk memperkenalkan ajaran toleransi dalam berinteraksi antara satu komunitas agama dengan yang lain."44

Terlepas dari perbedaan penafsiran di atas, pemaknaan istilah Ahl al-Kitab melalui beberapa penafsiran atas ayat ahl al-kitab telah mengalami pererduksian makna asalnya sebagaimana tekstualitas ayat. Penafsiran Ghalib misalnya, ingin mengembalikan pengertian ahl al-kitab pada makna asalnya sesuai tekstualitas ayat, meskipun meletakkan predikat kafir kepada mereka dalam hal teologis. ${ }^{45}$ lain halnya denga Tim Majlis Tarjih yang berusaha membangun kenetralan dalam hubungan sosial antar umat beragama melalui penafsiran-penafsiran kontekstualis sesuai tuntutan dan kebutuhan modern.

\section{Non-Muslim}

Upaya untuk menjelaskan konsep Non-Muslim menjadi penting dalam kaitannya dengan pergaulan dan interaksi sosial umat beragama. Urgensi tersebut semakin dikokohkan dengan dinamika hubungan umat beragama di Indonesia yang mengalami pasang surut setiap waktu, sedangkan karya tafsir Indonesia dalam soal ini memaparkan konsepsi yang beragam. Namun, pengertian dari beberapa penafsiran ulama' di Indonesia memposisikan terma Non-Muslim mencakup makna Kafir dan Ahli Kitab. Dengan demikian Non-Muslim jelas merupakan identitas distingsi yang melekat dalam wilayah keyakinan beragama antar Muslim dan "Non-Muslim" pemeluk agama selain Islam.

Penjelasan tafsir di Indonesia tentang pengertian dan cakupan Non-Muslim berdasarkan keterangan ayat al-Qur'an, banyak yang menghubungkannya dengan konsep kafir dan ahli kitab. Hal ini tidak lepas dari keterangan ayat al-Qur'an yang menjelaskan tentang perbedaan keyakinan umat Islam dan lainya tentang Allah dan rasulnya hanya dijelaskan dalam menggunkan istilah kafir, ahli kitab dan musyrik. Namun, pada esensinya pengertian dan cakupan Non-Muslim dalam al-Qur'an berdasarkan penafsiran terletak pada aspek hubungan antar umat beragama.

Terdapat beberapa penafsiran ulama' tentang hubunngan antar umat beragama, salah satunya Quraish Shihab dalam Membumikan Al-Qur'an, menurutnya penjelasan

\footnotetext{
44 Tim Majelis Tarjih dan Pengembangan Pemikiran Islam, “Tafsir Tematik al-Qur'an tentang Hubungan sosial antar umat beragama”(Yogyakarta: Pustaka SM, 2000), hal. 151-152

${ }^{45}$ Muhammad Ghalib, Ahl Al-Kitab, Makna dan Cakupannya, (Jakarta: Paramadina, 1998), 68.
} 
surat Al-Baqarah ayat 265 cukup jelas dalam menguraikan bahwa kebebasan beragama yang dibangun atas dasar sukarela harus melaksanakan ajaran-ajarannya dan pemeliharaan atas keyakinan yang dianut. Pendapat ini tentu tidak hanya berlaku bagi umat Islam, sebab konsep dasar kebebasan beragama selaian atas dasar sukarela, umat beragam harus responsip akan keyakinannya masing-masing. Bangunan kebebasan beragama adalah langkah awal untuk membangun hubungan atar keyakinan umat Islam dan Non-Muslim.

Dalam konteks hubungan sosiologis antar umat beragama, berdasarkan penafsiran Tim Badan Wakaf UII atas Surat Ali Imron ayat 28, bahwa larangan Allah terhadap umat Islam berhubungan akrab dengan orang kafir dalam aspek kekerabatan, persahabatan, ataupun bertetangga, berkaitan dengan faktor penghianatan, kemunafikan dan kemunafikan orang kafir. Namun, bentuk persahabatan dan persetujuan kerja sama yang dapat menjamin kemaslahatan orang Islam tidaklah dilarang. Nabi sendiri pernah mengadakan perjanjian persahabatan dengan Bani Khuza'ah yang musyrik.

Namun, terdapat perbedaan penafsiran ayat tentang Non-Muslim dalam kaitannya dengan penafsiran surat Ali Imron ayat 51-53 tentang konsep awliya' yang dinisbatkan kepada non-muslim. Tafsir Al-Hijri dalam menafsirkan kata awliya' memaknainya sebagai "pemimpin”. Penafsiran tersebut sebetulnya merupakan bentuk penyempitan makna. Sebab, menurut Quraish, makna dasar dari kata wali adalah "dekat", yang kemudian berkembang makna-makna baru, seperti pendukung, pembela, pelindung, dan seterusnya.

Penyempitan makna pada penafsiran di atas, tidak lepas dari kepentingan untuk membangun institusi Islam sebagai kerangka dasar dalam kepemimpinan. Pada aspek lain, pemilihan pemimpin, dianggap bukan hanya berdasarkan keahlian social maupun politik, akan tetapi factor keyakinan juga menjadi ukuran sebagai bentuk formalisme dan kelembagaan agama, dalam hal ini Islam, kaitannya dengan bersikap dalam ruang social politik di Indonesia, tentu akan melahirkan persoalan. Sebab, seperti kita tahu, di samping bukan negara yang secara intitusional Islam, Indonesia dalam kenyataannya merupakan negara yang terdiri dari banyak agama.Dengan demikian Perbedaan penafsiran terhadap pola hubungan yang dibangun umat Muslim terhadap non-muslim hanya berkaitan dalam aspek sosiologis. 


\section{Penutup}

Lokalitas Tafsir Nusantara memiliki perbedaan kecenderungan pada setiap periodenya. Dinamika metode dan pendekatan seakan menemui anti klimaks pada periode kontemporer yang bernuansa sosial-kemasyarakatan. Melalui metode tematik dan pendektan kontekstualis, jauh berbeda dengan periode sebelumnya, apalagi berkaitan dengan penafsiran tentang tema kafir, ahli kitab dan non-muslim. Penafsiran terhadap tema-tema tersebut pada periode modern banyak dilakukan untuk menemukan pemahaman yang dianggap esensial dan kontekstual sesuai dengan problem yang dihadapi umat islam. Pola hubungan sosial antar umat beragama menjadi sentralitas dalam pembahasan tematik Ayat-ayat Kafir, Ahli Kitab dan Non-Muslim yang sepintas merupakan konsep pola hubungan umat muslim terhadap non-muslim dalam aspek teologis dan sosialogis.

Penafsiran tentang konsep pola hubungan toelogis hampir tidak terdapat pertentang diantara para ulama' tafsir kaitannya dengan makna kafir, ahli kitab dan non-muslim. Ketiganya mendiskripsikan indentitas keyakikan yang berbeda dengan Islam, sehingga pola hubungan antar keyakinan umat beragama banyak disandarkan pada keterangan ayat Al-Baqarah 265 tentang kebebasan dan tidak ada paksaan dalam beragama. Keterangan serupa terdapat pula surat Al-Kafirun dengan jelas menyebutkan tentang sikap seorang muslim terhadap non-muslim yang banyak dipahami sebagai konsep toleransi dalam perbedaan keyakinan.

Namun, ayat-ayat yang dikaitkan dengan konteks sosiologis tentu sangat berbeda pada aspek teologi, problem sosial yang dihadapi umat Islam niscaya terus mengalami perubahan yang dinamis disetiap masanya. Perkembangan tafsir secara dialektis juga mengindikasikan hal serupa berkenaan dengan berbagai problem kehidupan manusia. Hal ini tentu berbanding terbalik dengan tekstualitas ayat alQur'an yang terbatas dan stagnan, sehingga kemunculan kecenderungan periode modern adalah bias dari perubahan zaman dan akan berimplikasi terhadap perbedaan penafsiran terutama kaitannya dengan tema sosiologis.

Diatas sudah penulis uraikan, perbedaan penafsiran tentang makna Kafir dan pola hubungan seorang muslim denganya dalam arti teologis dan sosiologis. Penafsiran tematik ayat-ayat kafir seringkali banyak direduksi kedalam makna sosialnya, sehingga 
penafsirannya pun banyak mengalami penyempitan makna dan bahkan lepas dari makna awalnya. Seperti contoh penafsiran pada surat Al-Maidah ayat 51 tentang konsep larangan menjadikan orang kafir sebagai "auliya"” dalam maknanya sebagai teman setia atau pemimpin. Hamka misalnya menafsirkan kata tersebut sebagai pemimpin, jelas berbeda dengan penafsiran Quraish Shihab yang memaknainya sebagai teman setia.

Penafsiran Hamka pada dasarnya tidak mengacu terhadap makna asal lafadz Auliya' dalam arti tekstualitas dan kontekstualitas ayat berkaitan dengan hubungan tersebut berkaitan dengan hubungan sosiologis. Dengan demikian persepsi yang berkembang dimasyarakat tentang pemimpin kafir yang disandarkan pada keterangan surat Al-Maidah ayat 51 perlu untuk memahami mendalam kontekstualitas ayat tersebut dan korelasinya dengan ayat lainnya. Qurais Shihab dalam sebagai ulama' tafsir periode kontemporer di Indonesia mampu menghadirkan suatu produk penafsiran yang tidak melepaskan aspek tekstualitas dan kontekstualitas ayat.

Demikian pula perbedaan penafsiran tentang makna dan cakupan Ahli Kitab dalam al-Qur'an antara penafsiran Muhammad Ghalib dan Tim Majelis Tarjih Muhammadiyah. Meskipun penafsiran keduanya hadir pada periode kontemporer, akan tetapi memiliki kecenderungan berbeda dalam memahami makna ayat-ayat tentang pengertiandan cakupan ahli kitab dalam al-Qur'an. Ghalib dalam hal ini tidak menggunakan pendektan kontekstual, sehingga pengertian ahli kitab merupakan komunitas Yahudi dan Nasrani sesuai keterangan tekstualitas al-Qur'an. Lain halnya Tim Majelis Tarjih yang berusah memaknai pengertian dan cakupan ahli kitab secara lebih luas sebagai komunitas pemeluk agama-agama samawi dengan kitab sucinya yang berbeda-beda. Meraka memahami kontesktualitas ayat ahli sebagai teks yang akan tetap relevan hingga saat ini.

Pemaknaan kafir dan ahli kitab erat kaitannya dengan terma non-muslim sebagai identitas keyakinan agama selain Islam. Penafsiran ayat-ayat non-muslim banyak dikaitkan dalam bentuk pola hubungan umat muslim dengan orang kafir dan ahli kitab baik Yahudi dan Nasrani. Pola hubungan yang dihadirkan pun, mencakup aspek teologis maupun sosiologis. Hanya saja seperti penjelasan sebelumnya, bahwa kebabasan beragama menjadi konsepsi awal hubungan ini. Konsep toleransi dalam menghormati dan menghargai perbedaan keyakinan orang lain akan memabawa pada 
kerukukan antar umat beragama. Selanjutnya persoalan hubungan sosiologi yang disandarkan pada keterangan penafsiran yang berbeda, tentunya tidak sampai merusak konsep dasar dan bahkan tafsir harus diduduk lagi pada kebenarannya yang bersifat nisbi. Hal ini tentu diperlukan untuk menanggapi berbagai produk penafsiran periode kontemporer yang berbeda-beda terutama kaitannya dengan persoalan sosiologis.

\section{Daftar Pustaka}

Azra, Azyurmadi 2011 Jaringan Ulama Timur Tengah dan Kepulauan Nusantara Abad, XVII-XVIII; Edisi Perenial, (Jakarta: Kencana Prenada Media Group)

Wijaya, Aksin 2011 Menusantarakan Islam, Menelusuri Jejak Pergumulan Islam Yang Tak Kunjung Usai, (Yogyakarta: Nadi Pustaka), 34.

Baidan, Nasruddin 2002 Sejarah Perkembangan Tafsir di Indonesia, (Yogyakarta: Tiga Serangkai), 21

Jhons, Anthony 1998 “The Qur'anic in the Malay World: Reflection on Abd Ra'uf of Sinkel (1615-1693)”, Journal of Islamic Studies 9:2, 121.

Yunus, Mahmud 1973 Tafsir al-Qur'an al-Karim, (Jakarta: PT. Hidakarya Agung), iii

Federspiel, Howard 1996 Kajian al-Qur'an di Indonesia, terj. Tajul Arifin (Bandung: Mizan), 39.

Mustaqim, Abdul 2009 Epistemologi Tafsir Kontemporer, (Yogyakarta: Penerbit LKiS), 26.

Gusmian, Islah 2003 Khazanah Tafsir Indonesia; dari Heurmeneutika hingga Ideologi (Jakarta: Teraju), 65

Baidan, Nashruddin 2003 Perkembangan Tafsir di Indonesia (Solo: Tiga Serangkai), 31-109.

R. Feener, Michael 1998 "Notes Towards", dalam Studia Islamika, Vol. 5, No. 3, 47.

Jons, A. H. 1989 "Islam di Dunia Melayu" dalam Azyumardi\| Azra (ed.) Perspektif Islam Asia Tenggara (Jakarta: Yayasan Obor Indonesia), 126.

Burhanuddin, Mamat S. 2006 Hermeuneutik al-Qur'an ala Pesantren: Analisis Terhadap Tafsir Marah Labid Karya K.H. Nawawi Banten (Yogyakarta: UII Press), 116-117.

Iskandar, Mohammad 1992 Para Pengemban Amanat, (Yogyakarta, Bulan Bintang) hal. 168

Hamkan, 2000 Tafsir Al-Azhar, (Jakarta: Pustaka Panjimas), Jilid I, 26

Ghalib, Muhammad 1998 Ahl Al-Kitab, Makna dan Cakupannya, (Jakarta: Paramadina), 62-63

Cawidu, Harifuddin Konsep Kufr dalam Al-Quran, hal 160-161

Al-Jaza'iri, Abu Bakr Jabir 1976 Minhaj Al-Muslim (Beirut: Dar Al-Fikr) hal. 535

Shihab, Quraish 2002 Wawasan, (Jakarta: Lentera Hati), 348

2002 Membumikan Al-Qur'an, (Jakarta: Lentera Hati), 368

2010 Tafsir Al-Misbah, (Jakarta: Lentera Hati), Jilid. 30, 143

Madjid, Nurcholish 2000 Islam Agama Peradaban: Membangun Makna dan Relefansi Doktrin Islam dalam Sejarah. (Jakarta: Paramadina), 188-190 
Adh-Dhahaby, Muhammad Husein 1998 al-Tafsir wa al-Mufassirun, (Beirut: Dar Kitab al-Islamy), Jilid I, 121-122

Al-Wahidy, 1996 Asbab an-Nuzul al-Qur'an, (Beirut: Dar Kutub al-Islamy), 156.

Tim Majelis Tarjih dan Pengembangan Pemikiran Islam, 2000 "Tafsir Tematik alQur'an tentang Hubungan sosial antar umat beragama"(Yogyakarta: Pustaka SM), hal. 151-152

Tim Badan Wakaf UII, Al-Qur'an dan Tafsirnya, I: 551-552. Lihat juga ketika tafsir ini menguraikan QS. An-Nisa (4):331

Hafidhuddin, Didin Tafsir Al-Hijri, tafsir Al-Qurn Surat Al-Maidah, hal.10. lihat juga dalam Tafsir Al-Hijri, Tafsir Al-Qur' an Surat An-Nisa', hal. 189

Hamka, 2000 Tafsir Al-Azhar, (Jakarta: Pustaka Panjimas), Jilid, 30, 67. 